\title{
APPLICATION OF CONTEXTUAL TEACHING LEARNING TO LEARNING RESULTS IN UNDERSTANDING THE LIFE ENVIRONMENT IN SMP NEGERI 2 SUKODONO
}

\author{
Elan Artono Nurdin ${ }^{1}$, Fahrudi Ahwan Ikhsan ${ }^{1}$, Fahmi Arif Kurnianto ${ }^{1}$, Bejo Apriyanto ${ }^{1}$ \\ Departement of Geography Education \\ University of Jember, Indonesia \\ E-mail: elan.fkip@unej.ac.id
}

DOI : 10.19184/geosi.v1i1.6189

\begin{abstract}
Article Info: Received Date $27^{\text {th }}$ November 2017, Received in revised from date $4^{\text {th }}$ December 2017, Accepted Date $7^{\text {th }}$ December 2017, Publish Date 14 ${ }^{\text {th }}$ December 2017
\end{abstract}

\begin{abstract}
This study aims to determine the improvement of learning outcomes geography by applying Contextual Teaching and Learning (CTL) on the concept of environmental pollution. This research was conducted at SMPN 2 Sukodono, Lumajang. The method used in this study is the method Classroom Action Research (CAR), PTK is implemented as an effort to overcome problems that arise in certain classes. This method is done with four stages, namely planning, action, observation, and reflection. The four stages are cycles that take place repeatedly and carried out with the same steps and focused on learning Contextual Teaching and Learning (CTL). Based on the results research that has been done shows that student learning outcomes increased. This increase can be seen through the cycle have been done. In the first cycle the average student learning outcomes were 54.76 at the time of the pretest and 77.46 at the time of post-test. While in the second cycle the average student learning outcomes 48.33 at pretest and 78.28 at posttest.
\end{abstract}

key words : Contextual Teaching and Learning, Learning Outcomes, SMPN 2 Sukodono

\section{INTRODUCTION}

Social studies learning in environmental problem material at Sukodono Junior High School 2 is generally still dominated by teacher activity. Classes focus on teachers as the main source of knowledge and Teaching and Learning Activities that are guided only by textbooks. So that learning activities do not provide opportunities for students to interact with concrete objects in real situations. This matter resulting in students not caring about what happened in the environmentaround it. Therefore the teacher should give concrete examples in every learning so that students can be responsive and caring for the environment in which the student lives. At the initial observation at SMP 2 Sukodono shows the fact that environmental 
conditions are in the area mining of cement raw materials experiences a variety of good soil contamination,air and water are not accompanied by students' concern for the problem.

This can be seen from the lack of attention from students to the problem environmental pollution that occurs in the area around his residence, even students do not seem to care about the pollution problems that occur with as if nothing had happened. In addition, the results of observations in the process of teaching and learning activities, these activities only run theoretically and are not related to real environment where students are. Observation results of student learning completeness only reached $60 \%$. The incompleteness of student learning outcomes is influenced by many factors, such as inadequate school facilities, selection of methods inaccurate learning, learning media is less interesting and level low student activity. Lack of community care, school and the teacher's role results in less than optimal results. To overcome this problem, a strategy is needed learning that empowers students more, namely an approach learning that is able to educate students with experience and the environment.

Contextual Teaching and Learning (CTL) is expected to be more effective learning, because students will learn more active in thinking and understanding material in groups. CTL can facilitate students in absorbing subject matter, and students can strengthen understanding of the amount of subject matter. Therefore the need to carry out Class Action Research at SMPN 2 Sukodono with the hope that learning outcomes can improve accordingly with a meaningful learning process.

\section{METHODS}

Action research for this class in 2 cycles. Every cycle is a process flow of activities that includes planning (Planning), Acting, observing, and reflecting (reflecting). The series of activities aims to direct students to learning problems and confirm that the cycle is going well. Before the research activities are carried out, it is necessary beforehand make preparations which will later be needed in research activities. The activities that have been carried out at this stage, this preparation is: (a) Initial observations are carried out to identify problems through interview with biology study teachers, then together the teacher determines the form of problem solving in the form of application contextual learning model on the concept of environmental pollution; (b) Prepared learning tools (making lesson units, plans learning, WORKS SHEET, preparing tools and materials for practicum); (c) Arranged instruments and observation sheets to observe activities students; (d) Prepared test questions; (e) Trial questions in other classes are carried out with a number of questions 30 item; (f) Analyzed the results of the test questions which include: question validity, reliability the question, the level of difficulty and the differentiating problem. 


\section{RESULTS AND DISCUSSION}

The planning stage in the first cycle begins with preparing everything something related to the design of learning that will be applied in this research. The preparation includes making an Implementation Plan Learning (RPP) using the CTL learning approach. The contextual learning approach was chosen because it can link environment and student understanding. Application of this contextual learning expected to encourage students' interests, motivations and activeness in the process learning, so that it can improve student learning outcomes optimally. Contextual learning is the concept of learning that helps teachers linking learning material taught with real world situations students and encourage students to make connections between knowledge owned by its application in everyday life.

Learning contextualization prioritizes knowledge and experience or the real world (real world learning), high-level thinking, student-centered, active students, critical, creative, solving problems, students learning fun, exciting, not boring, and uses a variety of learning resources. 51 The results of observations that researchers conducted on schools show that teaching and learning activities carried out in the morning, the classroom is sufficient so no students enter during the day, schools are in rural areas and close to residential areas, school infrastructure is still not complete, most students who study at this school are surrounding communities school, a minimum score set for social studies subjects is 70 .

After being discussed with the teacher concerned, it was decided the concept that is deemed necessary to be developed is the concept of environmental pollution. The concept of environmental pollution is taken because of the environmental conditions in the mining area of various raw materials for cement good pollution of land, air and water is not accompanied by the concern of students against the problem. This can be seen from the absence of attention from students on environmental pollution problems that occur in the area around the place where he lives, even students seem unconcerned about problems pollution that occurs with as if nothing has happened. Furthermore, researchers discuss with subject teachers in making lesson plans compiled based on the 2006 curriculum (KTSP). The concepts taught in the first cycle consist of sub-concepts of felling. Forests at the first meeting and air pollution at the second meeting. These concepts are delivered with the help of works sheet, where worksheets are carried out in groups. The group in the first cycle is formed by division randomly regardless of the abilities of each individual, with the hopes of the group formed can work together well without it rely on each other.

Based on observations made during the learning process take place, it can be seen that the division of groups is done randomly and evenly distributed, each group consisted of male and female students without see students' abilities. Each group puts the name of the group above 
group table. Some students do not want to gather with groups that are already set by the teacher. The student only wants one group with friends they want, besides that there are still many students joking when learning takes place.

CTL learning and have never experienced learning with a model that is. Students are not used to using the CTL learning model so that the first time the learning took place the learning atmosphere was still visible ambiguous. Implementation of the CTL learning model using work sheet applied to the first meeting in cycle I. Students are less conducive and still lazy in working on work sheet. The process of thinking together working on work sheet is still not optimal, only a few students dominate in groups. In this meeting, individual responsibility still not enough. In addition, there was an error in working on the worksheets due to students do not pay attention to the teacher's instructions. Material reinforcement is given when students ask about the concept not yet understood. Then the teacher and students together make a conclusion about concepts that need to be memorized. Some active students make notes about the most important concepts and other students not pay attention to conclusions let alone take notes.

Based on the results of the calculation of the initial ability test research data (pretest) students get the lowest value 15 from range 1 to 100 and value the highest 70 with a class average of 42.56 and a standard deviation of 13.08. At the end of the cycle I ability test obtained an increase in value the lowest student is 60 and the highest value is 85 . The average grade reaches 74.92 with a standard deviation of 6.32 . In the first cycle the average student learning outcomes were 54.76 at the time of the pretest and 77.46 at the time of post-test. While in the second cycle the average student learning outcomes 48.33 at pretest and 78.28 at posttest.

Data on improving student learning outcomes in the first cycle can know from the results student learning after experiencing learning with CTL on cognitive aspects is a multiple choice (multiple choice) objective test obtained results

as follows:

Table 1. General data

\begin{tabular}{ccc}
\hline Statistic & Pre Test & Post Test \\
\hline lowest score & 15 & 60 \\
highest score & 70 & 85 \\
mean & 40,14 & 71,39 \\
median & 42,5 & 75 \\
modus & 45 & 75 \\
Standar deviation & 13,08 & 7,58 \\
\hline total sample & 36 & 76 \\
\hline
\end{tabular}

Data processed (2018)

Learning outcomes in the first cycle before learning is done lowest value 15 and the highest score only reaches 70 , median is 42.5 , the value most students get (mode) is 45 , the 
value the average pretest score of 40.14 with a standard deviation of 13.08 . After experiencing learning with CTL, learning outcomes increase, with value the lowest is 60 and the highest value reaches 85 , the middle value (median) is 75 , the value the most obtained by students (mode) is 75 , the average value of the pretest score 71.39 with a standard deviation of 7.58 . But in the final test result (posttest) the first cycle was only 21 students who achieved the KKM score with a percentage of success amounting to $58.33 \%$.

At the planning stage in the first cycle the teacher plans learning to be applied with CTL, determine the subject matter, developing learning scenarios, preparing instruments (mastery tests concept), formation of student learning groups, and preparing learning resources. Then proceed to the action stage. At the action stage, namely with apply learning with CTL that is written in the learning scenario / Learning Implementation Plan (RPP). The series of activities at the first meeting is the Teacher gives apperception and motivation by asking students "what comes to mind your mind when you hear Bald Forest? What happens when the forest bald rain? What impact will it have? "(Principle asking). Teacher give a picture of the bald forest and dense forests to students with give an example of 2 children who have one short hair and one long hair to move forward. Then the teacher explains what is occurs when both are doused with water (modeling principle).

Teacher guide students to form heterogeneous discussion groups that are consists of 45 people with different intelligence, and each group members have their respective roles (the principle of the learning community). The teacher gives works sheet 1 about deforestation and deforested forest (principle constructivism). The teacher asks students to look for various reasons why people do logging (inquiry principle). The teacher asks each group explain the answer to the results of the discussion (principle of reflection). The teacher gives score of each group answer (actual assessment principle).

The results of the observation (observation) in the first cycle of the first meeting are: On the beginning of learning the classroom atmosphere was not conducive, the class atmosphere was still visible not yet orderly because students are not used to learning with CTL so that when learning begins there are still students joking when taking lessons. At the discussion stage to work on the works sheet the discussion was not going well, some students were still joking with friends and students still not used to discussing learning so there are still many from each group asking questions.

At the stage of carrying out an investigation or observation of cooperation the group has not been well established, some of the students still rely on it smart friend. When presenting the results of student group work yet look brave in presenting the results of discussion and observation of students, because students are not used to presenting the results of student 
discussions. The activity carried out at the second meeting was the Teacher giving apperception and motivation by asking students "Why the smoke of a motorized vehicle is black? "(asas asked).

Teacher simulates air pollution by burning the mosquito repellent the smoke is stored in jars containing a cricket (modeling principle). The teacher instructs students to sit in groups (the principle of the learning community). The teacher gives works sheet 2 about air pollution (the principle of constructivism). The teacher asks students to look for types of material that can pollute the air (principle inquiry). The teacher asks each group to explain the answers to the results of the discussion the (principle of reflection).

The results of the study are in accordance with the following opinions. CTL is a strategy that involves students in full in the learning process. Students are encouraged to move learn the subject matter to be learned. Mulyasa (2009: 217-218) states: CTL is a concept that emphasizes the interrelationship between learning platform with the life world of students real, so that students are able to connect and apply learning outcomes competencies in daily life -day. In line with this understanding, Sanjaya (2009: 255) explained that: "CTL is a learning strategy emphasize the process of full student involvement to get find the material studied and connect it with real life situations that encourage students to get apply it in their lives. Based on the opinion above, it can be concluded that the model CTL learning is a learning process that involves students in learning so students can construct their own knowledge and their learning skills obtained with experience directly so that the learning process will be more effective and meaningful, because learning here is not only memorizing but understanding.

Activities are all activities or a series of learning activities that occurs in a learning process that is like listen, take notes, and answer questions from the teacher. Activity is a principle or principle that is very important in learning interactions teach. Because in principle learning is doing. There is no learning if there is no activity. Teaching in school also comes alive as activity in life in society. In line with things that, Nasution (2004: 89) revealed that "children think as long as he does. So without the act of the child it is said no thinking, so that children can think for themselves then they must given the opportunity to be able to do it alone. Because children will think and find new answers after the child has done something. Furthermore Sardiman (2010: 24) states: "Learning as a process of interaction between human beings and their environment it may be personal, facts, concepts or theories.

Hamalik (2004: 30) explains that, "Learning outcomes is evidence of a change in one's behavior, which is seen in aspects such as; aspects of knowledge, understanding, habits, skills, appreciation, emotional, social, physical relationships, ethical character, and attitude. Sukardi (2009: 215) explains that learning outcomes are "The value that shows the achievement of 
student learning outcomes. Based on the explanation above, can be concluded that the learning outcomes is a form of ability and intelligence obtained by students as a result of the learning process which includes cognitive, affective, and psychomotor.

\section{CONCLUSION}

Based on the results of research, data analysis and discussion of research obtained conclusion that environmental learning by using contextual tecahing learning model can increase students' learning results. this finding will be very effective especially in material relating to concrete concepts. The teacher's ability to master the tool greatly affects the motivation and student learning outcomes

\section{REFERENCES}

Hamalik, Oemar. 2004. Proses Belajar Mengajar. Bumi Aksara. Jakarta.

Mulyasa. 2009. Praktik Penelitian Tindakan Kelas. Bandung: Rosdakarya

Nasution. 2004. Sosiologi Pendidikan. Jakarta: PT Rineka Cipta.

Sanjaya, Wina. 2009. Strategi Pembelajaran Berorientasi Standar Proses. Pendidikan. Prenada : Jakarta.

Sardiman. 2010. Interaksi dan Motivasi Belajar Mengajar. Jakarta: PT. Raja Grafindo.

Sukardi. 2009. Metodologi Penelitian Pendidikan(Kompetensi dan Praktiknya). Jakarta: Bumi Aksara 